\title{
Empirical Analysis of the Economic Benefits of Free Ports and Their Challenges to Ghana: A Cross-Sectional Survey of Tema Harbour
}

\author{
Ebenezer Nickson Neequaye*, Dechun Huang\#, Nelson Amowine, Stella Fynn \\ Institute of Industrial Economics, Hohai Business School, Hohai University, Nanjing, China \\ Email: *npapacy@yahoo.com, ${ }^{\#}$ huangdechun@hhu.edu.cn, amowinenelson@yahoo.com, fynnstella@yahoo.com
}

How to cite this paper: Neequaye, E.N., Huang, D.C. Amowine, N. and Fynn, S. (2018) Empirical Analysis of the Economic Benefits of Free Ports and Their Challenges to Ghana: A Cross-Sectional Survey of Tema Harbour. Open Journal of Social Sciences, 6, 180-196.

https://doi.org/10.4236/jss.2018.64016

Received: March 22, 2018

Accepted: April 24, 2018

Published: April 28, 2018

Copyright $\odot 2018$ by authors and Scientific Research Publishing Inc. This work is licensed under the Creative Commons Attribution International License (CC BY 4.0).

http://creativecommons.org/licenses/by/4.0/

\begin{abstract}
Free ports have existed for centuries. However, free countries have taken the initiative to adopt free port policies. This paper took a look at some economic benefits of free port in Ghana and the possible challenges that the country is likely to face adopting such policies. The study adopted a survey method where questionnaires were administered to 300 respondents. It was found that free port policy has both economic benefits as well as costs. Regardless of the economic situation within which a country finds itself, the concept of free port policy should be an ideal trade policy for all nations across the globe. To gain economically from free port policy, countries must be cognizant of certain challenges and accordingly address them.
\end{abstract}

\section{Keywords}

Free Port, Foreign Investment, Local Firms, Government Revenue, Economic Growth

\section{Introduction}

Liberalization of trade in goods and services, improvement in transportation, information and communication technology (ICT), combined with free-market ideology have resulted in expeditious mobility of goods and services across borders. And therefore, regional economies across the world are quickly incorporated into a global economy. In the year 2008 alone, about 8.2 billion tons of international freight, which was almost $75 \%$ of total trade, was transported by sea at a very low cost [1]. There has been increased level of competition resulted in public sector and private sector organizations recognizing the need to transform from national and regional business strategies to global business strategies [2]. 
Apart from benefits to customs taxes and duties, free ports usually also support economic activity through many monetary incentives including research and development, tax credits, regulatory flexibility, and tax reductions. There are about 3500 free ports worldwide, employing 66 million people across 135 countries [3]. The United States is home to over 250 free port, which employ 420,000 people and handle $\$ 750$ bn of merchandise. They have played a major role in retaining, re-shoring and growing domestic manufacturing activity and boosting trade [3].

It has also been estimated that another economic benefit that will accrue from free port that employment would disproportionately be created in manufacturing rather than services. Experience in free-port countries shows that Free Ports incentivise domestic manufacturing and processing activity. This is especially seen in sectors like pharmaceuticals, vehicle production, and chemicals, and in global companies where supply chain components move back and forth [3].

From the foregoing, it has become lucid that free ports undeniably, will economically benefit Ghana and most of third world countries in myriad ways. However, several thorny problems have been identified in Ghanaian ports. There are many infrastructural challenges. Since the ports were constructed no major refurbishment has taken place. Expansion work on the Takoradi ports has proved to be virtually impossible as it is edged by the municipality. The equipment present has also not been upgraded and technology is out-date [4] [5] [6]. In addition, the Black Star Line which was Ghana's national shipping line collapsed and was later sold off. Presently, the country has no national shipping line to facilitate the adoption of free port strategy in the country. Moreover, the plan to build Boankra inland port has been in limbo for more than 20 years. This port was to help ease congestion at Team and Takoradi Ports. There is also the under exploitation of waterways in the country [4]. Ghana is ranked as the 57th country with the most kilometres of waterways with our water bodies stretching about 1293 miles [4]. However, there is no inland port facility to facilitate transportation of cargo from our already existing ports along water ways making the operation of a free port in the country very difficult. In addition, the Atuabo Free Port Project has been in limbo since 2015 because of political stalemate and other impediments [6]. Therefore the primary aim of this paper is to examine the economic benefits that can accrue from free ports for Ghana as well as some possible challenges [7] that the country faces. The study was conduct to test the hypothesis that free port policy makes it possible for companies to enjoy tax exemptions which leads to increase investment that brings about more economic benefits to countries.

\section{Literature Review}

Free port (also called a free trade zone) is a zone adjoining a port that permits the duty-free entry of foreign goods intended for re-export. Thus, free port is an area adjoining a port where goods that are intended for reshipment can be received and stored without payment of duties [3]. 
Similarly, a study of OECD defines the concept as a government policy to promote exports of transit goods and/or services by offering a more competitive business environment through provision of special incentives including tariff exemptions to inputs [8]. Free port and free zone have been used interchangeably in this paper.

Free ports have existed for centuries. However, their recent development actually began in the 1960s. now, there are estimated There are approximately 3500 Free Trade Zones worldwide, employing 66 million people across 135 countries [3]. The classic Freeport is usually situated at a seaport or airport and bound by a natural barrier. This allows for warehousing and storage of goods, transhipment, minor processing and assembly operations [7].

\subsection{Features of Free Ports/Zones}

Based on the myriad definitions of the concept free port/zone, free-port economies exude the following features;

Geographically enclosed area, usually physically secured;

- Simplified administrative procedures with a view to decrease red-tape;

- Duty-free imports of raw materials and intermediate goods;

- Substantial tax incentives for the firms;

- Improved infrastructure services, which have generally better conditions than the rest of the host country [9] [10].

\subsection{Costs and Economic Benefits Generated by Free the Institution of Free Ports}

Free ports policy has both cost and benefits to nations that adopt such policies. According to Hanley et al., (2001) just as countries benefits from free ports policy, so they may suffer from adopting free port policy.

1) Possible costs of free port policy

Aside from the favourable effects and benefits that can be potentially achieved through the institution of free ports, there are costs and unfavourable effects as well. Unfavourable effects and costs limit the benefits of the zone operating. This renders it less attractive for goal achievement. First of all, mention must be made of its probable negative impact on the balance of payments, on employment, competitions with local industries and on government budget. These adverse effects are mostly connected to the adverse effects generated by foreign direct investments [7].

Another problem that may accompany the institution of free ports or zones has to do with huge capital investment. For instance, free zone operating in the Philippines led the negative net current values because there were very huge capital infrastructure costs which occurred at the beginning of the programme [7].

Even though it is almost a truism that free ports lead to employment, most of the available literature agrees that the situation leads to poor working conditions. [11], for example contends that there is wages paid in free port zones are 
usually lower than wages paid in home country. Cases in point are Costa Rica, Panama, Haiti and Pakistan.

There is also aggressive market entry policy. The domestic firms that have to encounter this aggressive import competition from foreign companies have no choice but to lower the prices of their products in order to defend their market share [12].

When free trade results in an imbalance of goods traded, someone suffers. Free ports may be detrimental to sectors development in the long run [13]. Countries that are poor and less diversified have problems capturing the opportunities arising from this liberal trade environment [14].

\section{2) Economic Benefits of Free Ports}

Instituting free port/zones has been a major influential improvement in economic development. To put it in other words, a free economic zone is a regional area in which foreign investors, sometimes in cooperation with domestic investors avail themselves of a set of regulations which serve as incentives for them and make them privileged over the investors in the ordinary economic zones. Under such circumstances they concentrate on the production of things which are then exported in other countries generating economic growth [15].

A free port offers many opportunities to improve free market activities and to "exploit comparative economic advantages" [16]. The establishment of free economic zones offers so many benefits for investors. Some of these benefits are: there are sometimes no export-import duties, no foreign exchange controls; they also enjoy tax exemptions, licensing, less strict labour legislation and better infrastructure [17].

The high quality of administration and living environment has turned free ports into centres for international finance. Because of this, they are hosting the headquarters of many multinational corporations, including major law firms, accountancy firms, IT companies and strategic consultant [18]. These zones are also transforming into multicultural centres for health services, education, tourism, leisure and shopping.

Establishing free ports also contributes colossally to the Gross Domestic Product (GDP) of the hosting country. For example, the Freeport of Riga contributes to the overall GDP of the country around 3\% [19]. This means that there was a potential increase in the cargo turnover which were kept in the port. This could help the country in the stabilization of its economy in the long run. One cannot be oblivious of the contribution that free ports make to employment. At the beginning of 2010, about 20 thousand people were employed in enterprises that run its operations on the grounds of the Freeport of Riga connected with the business of port. Also, but after putting the new terminals and infrastructure objects into operation, the number of employees was projected to directly and indirectly grow by at least 5 thousand. Also, approximately two thousand people were expected to involved in the implementation process of the Project of Krievu Sala [19]. The system of port dues and tariffs is one of the main benefits for free 
ports. And the Freeport of Riga regards as one of its benefits the system of tariffs and port dues as generally competitive and yielding strong financially positive results.

Free ports enjoy have almost access to transport facilities. This happens because most of the time free ports are situated close existing ports or airports. The zone tends to engage mostly in entrepot and trade operations (i.e. storage/warehousing). Developments close to the airports, for instance, will based in favour of business firms that can be serviced by the air cargo and this will invariably attract low volume and high value goods [2].

Establishing free ports contributes to the generation of foreign exchange earnings. It also positively affects the exchange rate. By promoting non-traditional exports, greater export earnings may have a positive impact on the exchange rate. The result is either greater imports at a given exchange rate, or imports at lower cost for domestic buyers [2].

Providing jobs and creating income. In developing countries workers in the agricultural sector move to better paid jobs in manufacturing. Shifting workers into industrial production has a low opportunity cost to the economy: the economy does not lose much agricultural output and gains additional output of non-traditional export goods [2]. Free ports also attract foreign direct investment (FDI) with a larger capital stock for the host country [2].

Finally, free ports/zones help in generating technological transfer, knowledge spill-over and demonstration effects. This will result in local companies engaging in production of non-traditional products. Local suppliers are on the gaining side for the reason that they are forced to manufacture at world-class production and quality standards which requires extensive training of labour, staff and management [2].

\section{Research Methods}

The study was conducted at the Tema Harbour. It is one of the main ports in Ghana. Lots of goods are transported by sea in and out of the country through the Tema Harbour. The study population included importers and exporters as well as transport operators in the Tema Harbour. The study population also included government/public sector workers within the Tema Harbour and private sector workers who do various transactions within the Tema Harbour.

The study target population were importer/exporters, staff at Tema Harbour, transport operator, government appointees. It included foreigner nationals and Ghanaians who have businesses and work with at the harbour for the at least five years.

The study employed quantitative approach. This technique was employed so as to help provide quantifiable data on challenge and economic benefits of free port in Ghana. According to [20], quantitative study is a research based on measurement of quantity or amount. Quantitative study is applicable to phenomena that can be expresses in terms of quantity [21]. It is used to answer questions about relationships measured variables with the purpose of explaining, 
predicting and controlling phenomenon [22]. For this reason, the research sought to collect quantifiable data that could be used for generalization purposes on challenges and economic benefits of free port so as to provide a better understanding on the rational countries need to adopt free port policy.

For the purpose of this research, social survey study was used. This type of design is also referred to as cross sectional study and is commonly used in the social science studies because of its advantage over other research type of study [21]. The social survey study comprises collection of data predominantly by questionnaire or by structured interview more than one case of single point in time [22]. As in the case of this paper, this design was employed because it entails the collection of data on more than one case and at a single point in time in order to collect a body of quantitative or quantifiable data in connection with two and more variables which are then examined to detect patterns of association [20].

The social survey design enabled the researcher to provide quantitative data in economic benefits of free port and the possible challenges face by countries in implementing free port policy. It also provided the researcher the opportunity to collect data from respondents (stakeholders in Ghana port) within necessary altering their behaviour.

This design was used in conducting the study because the researcher was not required to assign individual to comparison groups [20]. The design was employed in the study as it offers the researcher the chance to use probability sampling techniques, where data was randomly collected from various respondents within the port. This helped in collecting data that can be used to make generalization. This provided the study with a consistent benchmark where quantitative data can be collected to measure the phenomenon of study.

The paper combined both primary data collected from the field and secondary data on benefits of free port from articles and journal. The instrument used of the data collection was questionnaire. This technique of data collection was to help the researcher achieve the study objectives. Collection of data through the use of questionnaire made it possible for the researcher to collect the data within short time period appropriate for the study. The questionnaire instrument was also used to help provide quantitative data for inferences and generalization.

For the purpose of this study the researcher employed probability sampling technique in selecting the respondents for the study. This sampling technique provided the opportunity for all members within the target population to have equal chance of being part of the sample size [21]. It also made is possible to generalize the study findings as the data that was collected from representative sample of the larger population. In the first place, the researcher employed a stratified sampling to class the respondents into similar categories. These categories included importers and exporters as well as transport operators in the port industry. The study also selected government/public sector workers within the port. After stratified the respondents, the research used proportionate sampling to select representative sample from each group since the total population 
size in each category was different. The last stage of sampling was simple random sampling where a sample frame was obtained from each of the categories. The respondents were randomly selected using lottery methods from the sampling frame. A sample size of 300 respondents was selected for the study.

The quantitative approach was adopted in analysis of data. Completed questionnaires were entered on excel spread sheet. STATA version 11.1 was used to create a database on a password-protected laptop. Statistical evaluation was then performed, during which the answers were grouped and analyzed according to the challenges ad benefits of free port in Ghanaby means of the Chi-square test and one sample $\mathrm{T}$ test. The level of significance was fixed at $\mathrm{P}<$ 0.05 .

The data were checked for errors against the questionnaires. All missing values were confirmed from the questionnaires as missing. Missing values in this study were treated as responses not revealed by participants. A major challenge faced in conducting this study was delay from respondents in returning the research instrument within the initially planned time.

\section{Questionnaire Adopted in the Study}

\section{Demographic Characteristics of Respondents}

1) Sex (1) male [ ] (2) female [ ]

2) Age Group 1) Below 25 years [ ] 2) 36-45 years [ ] 3) 46 - 55 years [ ]

3) Highest Level of Education 1) SSCE or equivalent [ ] 2) Diploma [ ] 3) Degree [ ] 4) Masters [ ]

4) Occupation 1) Importer [ ] 2) Exporters [ ] 3) Staff at Tema Harbour [ ] 4) Transport operator [ ] 5) Government appointees [ ]

\section{Economic benefits that can accrue from free ports}

Using the scale from strongly disagreed $=1$ to strongly agree $=5$ indicated your level of agreement to the following statement as economic benefits of free port policy

Statement
Sree market activities help to exploit comparative
economic advantages
No foreign exchange controls;
No export-import duties,
Attract foreign direct investment
Enjoy tax exemptions
Generation of foreign exchange earnings.
Promoting non-traditional exports
Providing jobs and creating income.
Knowledge transfer
Better infrastructure




\section{Challenges of free port policy}

Using the scale from strongly disagreed $=1$ to strongly agree $=5$ indicated your level of agreement to the following statement as challenge of free port policy

\begin{tabular}{ccccc}
\hline Statement & SDS & D & U A SA \\
\hline Reduce government revenue & & & \\
Affect labour wages & & & \\
Dumping of inferior goods and services & & & \\
Affect employment & & & \\
Kill infant industries & & \\
Affect local industries & & \\
Foreign price influence & & \\
High capital investment & & \\
Limit foreign invest & & \\
Forest depletion & & \\
\end{tabular}

\section{Results of free port}

Using the scale from Strongly disagreed $=1$ to Strongly Agree $=5$ indicated your level of agreement to the following statement as economic possible outcomes of free port policy

\begin{tabular}{c} 
Statement \\
Increase employment \\
Increase in wages \\
\hline Improvement in government revenue generation \\
Expansive of local firms \\
Increase foreign reserve \\
High foreign exchange \\
Benefit from foreign products \\
Gain from foreign investment
\end{tabular}

\section{Analysis of Results and Discussion}

The study was conducted to examine the economic benefits that can accrue from free ports for Ghana as well as some possible challenges that the country is likely to face. To achieve these objectives, the researcher used questionnaire to collect data from 300 respondents. The results were presented based on the objectives and a brief background of the respondents.

\subsection{Demographic Characteristics of Respondents}

The study initially provided some background information regarding the re- 
spondents. This was to provide the study with useful information about the respondents involved in the study and how their demographic features could be of importance in influence people views regarding free port policies in Ghana.

Table 1 shows the number of the female respondents which was forty-two per cent $(42 \%)$ which is lower than that of the male, forth-eight per cent (58\%). Only four per cent (4\%) of the respondents were between the age bracket of $46-55$ years old, $86 \%$ of the respondents were between 36 - 45 years old and ten per cent $(10 \%)$ were 25 years or below.

Also, the respondents were to indicate their educational background and the research showed eight per cent $(8 \%)$ of the total respondents were masters degree holders. The survey indicates that greater number of the respondents were bachelor degree holders and they constituted thirty-eight per cent (38\%) of the total respondents. About twenty-two per cent (22\%) of the total respondents were diploma holders. Also, thirty per cent (30\%) of the respondents had their highest qualification being SSCE (Senior Secondary Certificate Examination) or its equivalent.

Background information was also collected on respondents' occupation. On this variable the study found that $42 \%$ of the respondents were importers/exporters, $14 \%$ of the respondents were staff at the Tema harbour, $34 \%$ of the respondents were transport operators who transport cargo and goods

Table 1. Demographic characteristics of respondents.

\begin{tabular}{|c|c|c|c|}
\hline $\begin{array}{l}\text { Demographic } \\
\text { Characteristics }\end{array}$ & Categories & Frequency & Percent \\
\hline \multirow[t]{3}{*}{ Sex } & Male & 174 & 58 \\
\hline & Female & 126 & 42 \\
\hline & Total & 300 & 100 \\
\hline \multirow[t]{4}{*}{ Age Group } & Below 25 years & 30 & 10 \\
\hline & 36 - 45 years & 258 & 86 \\
\hline & 46 - 55 years & 12 & 4 \\
\hline & Total & 300 & 100 \\
\hline Highest Level of & SSCE or equivalent & 90 & 30 \\
\hline \multirow[t]{4}{*}{ Education } & Diploma & 66 & 22 \\
\hline & Degree & 114 & 38 \\
\hline & Masters & 24 & 8 \\
\hline & Total & 300 & 100 \\
\hline \multirow[t]{5}{*}{ Occupation } & Importer/exporters & 126 & 42 \\
\hline & Staff at Tema Harbour & 42 & 14 \\
\hline & Transport operator & 102 & 34 \\
\hline & Government appointees & 30 & 10 \\
\hline & Total & 300 & 100 \\
\hline
\end{tabular}

Source: Field Data, 2018. 
to and from the port and $10 \%$ of the respondents were government appointees serving on various committee and boards, and various departments at the Tema harbour.

\subsection{Economic Benefits that Can Accrue from Free Ports}

According to [8] free port policy have many economic benefits. The importers and exporters stand to again when there are free port policies available in a country. When there are free port policies, the money that exporters and importers would have used to pay port levies are channelled to their trade to expand their business and create more employment opportunities for the citizens. The importance of free port policy cannot be underestimated in developing countries like Ghana where the economy heavily depends on importation of foreign products and few primary exports. Against this background, the researcher investigated the economic benefits of free port in Ghana. The benefits of free port policy were assessed. On a five point Likert scale, respondents were asked to indicate their level of agreement from $1=$ strongly disagree to $5=$ strongly agree. Descriptive statistics of one sample t-test were presented and analyzed. However, Cronbach's alpha was calculated for the items to show its reliability before the one-sample t-test was done.

\subsection{Reliability of Response for Economic Benefits of Free Port Policy}

The respondents' views regarding 10 items considered to be benefits of free port policy in Ghana were tested using Cronbach's Alpha coefficient. This was done for each individual free port benefit and presented under sub-headings. Table 2 below reveals a Cronbach's Alpha of 0.853 for the scale. This was done using the Reliability Analysis of SPSS. Since this figure is greater than 0.75 [23], the responses provided regarding the economic benefits of free port policy was reliable and can be used and relied upon for this study. According to Hinton, it is the measure of internal consistency, that is, how closely a set of items are as aroup. It is thus the measure of scale reliability.

\subsection{Economic Benefits of Free Port Policy}

The study used simple means, and standard deviations of each of the questions that were asked to determine the economic benefits of free port policy in Ghana. Using a rating scale for the factors considered as benefits of free port policy, a factor was considered as a beneficiary if it recorded a mean of 3.5 and above. Mean values of 4.0 indicates very beneficiary. The standard error is the standard deviation of sample means and it tells how similar a sample is likely to be of the population. A large standard error reflects a lot of variability between means of different samples and a small standard error suggests that most sample means are similar to the population [24]. Standard deviations of less than 1.0 signal that, there is little variability in the data collected and consistency in agreement among the respondents. 
Table 2. Reliability Statistic for economic benefits of free port policy.

\begin{tabular}{ccc}
\hline Cronbach's Alpha & $\begin{array}{c}\text { Cronbach's Alpha based on } \\
\text { Standardized Items }\end{array}$ & N of Items \\
\hline $\mathbf{0 . 8 4 8}$ & 0.853 & 10 \\
\hline
\end{tabular}

Source: Field Data, 2018.

From the data depicted in Table 3, the study found that there is small variability and more consistency in agreement among the respondents as the standard deviation for all the items on the scale was less than 1. It can also be realized that the standard errors of the means were all below one, also confirming consistency in responses.

From Table 3, it was found that most respondents agreed that free port policy has positive effect on many economic variables considered in this study. From the results presented in Table 3, the idea that free port policy brings about free market activities that help to importers and exporters companies to exploit comparative economic advantages ranked first with an average score of 4.58, which implied that most respondents strongly agreed that when there are free ports, exporting and importing companies gain from high competitive advantage which makes it possible for them to produce more. The second benefit of free port policy according to respondents was no or less foreign exchange control. The study found that the fact that free port policy will lead to no foreign exchange control recorded a mean score of 4.47 which was the second highest average score among the ten items considered to be the economic benefits of free port policy in Ghana. The average score of 4.47 implied that most respondents agreed that the introduction of free port policy will help avoid or reduce foreign exchange control in import and export which will bring much economic benefit to the country. The respondents were of the view that without foreign exchanges control export and import of goods and services into the country will be done with ease and promote economic growth.

Other important benefit of free port policy included; no or low export-import duties which placed $3^{\text {rd }}$ with an average of $(X=4.34)$, free port policy attracting foreign direct investment with mean score of $(X=4.29)$, companies enjoy tax exemptions as a result of free port policy with mean score of $(X=4.13)$, free port policy will lead to generation of foreign exchange earnings with mean score of $(\mathrm{X}=4.03)$, free port will promote non-traditional exports $(\mathrm{X}=3.96)$. The study equally found that some economic benefits of free port include; providing jobs and creating income, knowledge transfer and better infrastructure which recorded a mean score of $(\mathrm{X}=3.87,3.72$ and 3.61) respectively.

As reviews on previous studies, this study result further emphasis on the economic benefits of free port policy to both importing and exporting companies. The study revealed that free port policy was necessary if the world want to gain from the advent of technology. With globalization and increasing technology, it is less prudent for countries to continue imposing port charges on companies. The study results showed that both importers and exporters stand to gain from 
Table 3. Descriptive Statistics foreconomic benefits of free port policy.

\begin{tabular}{|c|c|c|c|c|c|}
\hline & \multicolumn{3}{|c|}{ Mean } & \multicolumn{2}{|c|}{ td. Deviation } \\
\hline & $\mathrm{N}$ & Statistic & Std. Error & Statistic & Rank \\
\hline $\begin{array}{l}\text { Free market activities help to exploit } \\
\text { comparative economic advantages }\end{array}$ & 300 & 4.58 & 0.057 & 0.534 & $1^{\text {st }}$ \\
\hline No foreign exchange controls; & 300 & 4.47 & 0.081 & 0.866 & $2^{\text {nd }}$ \\
\hline No export-import duties, & 300 & 4.34 & 0.068 & 0.730 & $3^{\text {rd }}$ \\
\hline Attract foreign direct investment & 300 & 4.29 & 0.064 & 0.682 & $4^{\text {th }}$ \\
\hline Enjoy tax exemptions & 300 & 4.13 & 0.063 & 0.672 & $5^{\text {th }}$ \\
\hline $\begin{array}{l}\text { Generation of foreign exchange } \\
\text { earnings. }\end{array}$ & 300 & 4.02 & 0.063 & 0.677 & $6^{\text {th }}$ \\
\hline Promoting non-traditional exports & 300 & 3.96 & 0.072 & 0.777 & $7^{\text {th }}$ \\
\hline Providing jobs and creating income. & 300 & 3.87 & 0.074 & 0.789 & $8^{\text {th }}$ \\
\hline Knowledge transfer & 300 & 3.72 & 0.069 & 0.564 & $9^{\text {th }}$ \\
\hline Better infrastructure & 300 & 3.61 & 0.061 & 0.619 & 10 \\
\hline
\end{tabular}

Source: Field Data, 2018.

free port policy. The study results further showed that the countries that export or import equally gain from free port policy. From the study results, it was found that free port policy attracts foreign direct investment. The implication here is that countries which implement free port policy economically stand to gain from more invest from foreigners who can invest to transform the economy. In the opinion of [8] free port policy help attract foreign investors which can lead to growth in a country economy. The data of the current also corroborates other studies by [1] and [17], which indicated that free port policy has several economic benefits including no export-import duties and tax exemptions for importers and exporters which lead to reduction in prices of goods and services.

\subsection{Challenges of Free Port Policy}

The idea of free port policy came as a result of the concept of trade liberalization. Although, free port policy is good, it has several negative consequences and the environment has become a pertinent issue in free port policy discussion, especially in the face of globalization and increased technology. Proponents of free port policy drawing inspiration mainly from the idea of David Recardo's theory of comparative advantage, argue that, liberalized trade increases incomes across countries. However, free port policy does have its own disadvantages which make it difficult for countries to easily accept and adopt the concept of free port policy. To determine the challenges of free port policy the study adopted a Likert scale rating from strongly disagreed $=1$ to strongly agreed $=5$ to scale a number of factors believed to be some disadvantages and challenges of free port policy. The results in Table 4 depict the detailed data; 
Table 4. Descriptive statistics for challenges of free port policy.

\begin{tabular}{ccccccc}
\hline & \multicolumn{4}{c}{ Mean } & \multicolumn{3}{c}{ Std. } \\
& \multicolumn{3}{c}{ Deviation } \\
\cline { 2 - 6 } & $\mathrm{N}$ & Statistic & Std. Error & Statistic & Rank \\
\hline Reduce government revenue & 300 & 4.65 & 0.062 & 0.545 & $1^{\text {st }}$ \\
Affect labour wages & 300 & 4.54 & 0.053 & 0.552 & $2^{\text {nd }}$ \\
Dumping of inferior goods and services & 300 & 4.51 & & & \\
Affect employment & 300 & 4.36 & 0.045 & 0.625 & $3^{\text {rd }}$ \\
Kill infant industries & 300 & 4.25 & 0.061 & 0.648 & $4^{\text {th }}$ \\
Affect local industries & 300 & 4.21 & 0.076 & 0.765 & $5^{\text {th }}$ \\
Foreign price influence & 300 & 4.20 & 0.052 & 0.532 & $6^{\text {th }}$ \\
High capital investment & 300 & 4.18 & 0.067 & 0.674 & $7^{\text {th }}$ \\
Limit foreign invest & 300 & 4.11 & 0.074 & 0.753 & $8^{\text {th }}$ \\
Forest depletion & 300 & 4.09 & 0.057 & 0.682 & $9^{\text {th }}$ \\
\hline
\end{tabular}

Source: Field Data, 2018.

From the results illustrated in Table 4, the study found that contrary to the economic advantage and benefits that free port policy may bring, some of the challenges that countries face in carrying out free trade policy include; reduced government revenue which ranked highest with a mean score of $X=4.65$ and forest depletion which ranked lowest, but yet with a mean score of $\mathrm{X}=4.09$ in a scale of nine factors considered as challenges of free port policy.

The study found that majority of the respondents agreed that free port policy adversely affects an economy in terms of wages workers received, lead to dumping of inferior goods and services into countries that received import goods and services. It was also noted that with free port policy in place, employment opportunities are limited as local companies in Ghana may not be able to produce to compete with foreign companies to expand their business to create employment for the local people. Aside this, the effects of free port policy on employment and wages of workers, the study noted that it also kills infant industries and affects local industries. Respondents indicated that most companies in Ghana were still producing at high cost. Thus, the cost of production in Ghana is high, and if there is free port policy, the resulting effects will be collapse of local industries. Other more serious challenges of free port policy are that prices of goods and services in Ghana will be determined by external factors which may be beyond the control of government of Ghana. The study found that free port policy will lead to foreign price influence in Ghana. The respondents further agreed that for companies in Ghana to enjoy free policy, it will require high capital investment which most companies cannot meet such requirement. From the results presented in Table 4, the study found that respondents cited limited foreign investment and forest depletion part of some of the challenges of free port policy. 
The study results were in line with previous scholars who have advocated against free port. According to [16] and [3], free port may have some advantages, but its negatives cannot be overlooked. The specialization in the production of goods in which exporter and importers have comparative advantage, leading to lower per unit cost of production and thereby making more goods available at relatively lower prices than would otherwise be the case. However, it does have challenges when a country cannot boast of much productive areas to gain from free port policy.

It is not noted that free port will certainly lead to increased world income. On the other hand, it is argued that the negative environmental consequences of increased output from liberalized trade may outweigh the gains from income [25]. According to [7], it not all countries that stand to again equally from free port policies. Some are at more disadvantageous position in adopting free port policy.

\subsection{Study Hypothesis}

The study was conducted to test the hypothesis that free port policy makes it possible for companies to enjoy tax exemptions which leads to increased investment, which in turn brings about more economic benefits (increase in employment, increase in wages, improvement in government revenue generation, expansive of local firms, increase foreign reserve, high foreign exchange, benefit from foreign products, gain from foreign investment to countries).

To test the research hypothesis, the researcher adopted a statistical tool such as the one sample T-Test. Statistical test using one sample t-test at $95 \%$ confidence interval and $5 \%$ level of significance was carried out to compare the means of the economic benefits resulting from free port policy as per the items on the Likert scale. It should be noted that the degree of freedom is 99 (n-1;100-1). This was done to find out which of the economic benefits of free port policy are significant in terms of Ghana adopting free port policy. From the Table 5, it can be seen that despite the list of economic benefits cited by respondents, most of economic benefits did not yield significant at .05 alpha.

From the results presented in Table 5, one possible economic benefit of free port policy of Ghana was benefit from foreign product. This recorded a p-value of $0.014<0.05$, which implied that there was significant relationship between free port policy and economic benefit such as benefits from foreign product. All the other factors considered yielded p-values $>0.05$, which implied that there were not significant relationships between free port policy and Ghana benefiting economically from such variables (increase employment, increase in wages, and improvement in government revenue generation, expansive of local firms, increase foreign reserve, high foreign exchange and gain from foreign investment).

The study results confirmed the views of [7] that free port policy have negative implications on countries that implement free trade. As noted by [15] and [7], unfavourable effects and costs of free port policy limit the economic benefits of the zone operating it. This renders it less attractive for goal achievement. [8] 
Table 5. One sample T-Test for economic benefits of free port.

\begin{tabular}{ccc}
\hline Economic benefits from free port policy & t-Statistic & Sig. (P-value) \\
\hline Increase employment & 9.241 & $0.514^{\star}$ \\
Increase in wages & 5.453 & 0.700 \\
Improvement in government revenue generation & 3.458 & $0.611^{\star}$ \\
Expansive of local firms & 2.871 & 0.073 \\
Increase foreign reserve & 0.985 & $0.413^{\star}$ \\
High foreign exchange & 1.934 & 0.329 \\
Benefit from foreign products & 2.212 & 0.014 \\
Gain from foreign investment & 0.082 & 0.632 \\
\hline
\end{tabular}

Source: Field Data, 2018.

made mention of the probable negative impact on the balance of payments, on employment, competitions with local industries and on government budget. Equally [7] cited some adverse effects of free port. The challenges of free port are mostly connected to the adverse effects generated by foreign direct investments. Another problem that may accompany the institution of free ports or zones has to do with huge capital investment. For instance, free zone operating in the Philippines led the negative net current values because there were very huge capital infrastructure costs which occurred at the beginning of the programme.

The scale of economic effect of free port policy reflects the tendency for it to create additional output resulting in deterioration of a country economy. Most forms of negative economic effects including pollution are by low or inferior products into countries with free port. Increased trade openness often implies an increase in economic activity. The scale effect, holding constant production techniques and the mix of goods produced, is likely to cause an increase in others with industries but lead to unemployment at countries lacking industries and reduction in government revenue generation which can affect other sector of the economy.

\section{Recommendations}

The study found that free port does have both advantages and disadvantages. Countries seeking to adopt free port must first consider guide against any negative consequence that free port may bring. For countries to gain from free port, the study suggested the following measures;

Countries should adopt free port policy to reflect in some aspect of the economy that will best benefit them. For instance, a country can adopt free port policy for some goods and services that it stands to gain from importers bring such goods to the country free from port duties.

Free port should be limited to some areas (sectors) and not universal. It should be implemented in areas that a country cannot produce its own goods in. This will help countries gain from competitive advantage. In doing so, free port 
policy should be restricted in that area alone and not to other sectors.

Government should support local firms if it to adopt free port. The reasons are that, free port will mean local firms will have to compete with foreign firms for available market local and international. In so doing, if government does not support local firms, they must have limit market which will not support expansion of their firms.

Government should implement free port policy that will make foreign firms establish their industry in the local country than producing outside and importing the goods. This will help create jobs for the local people and will subsequent increase consumption.

When free port policies are introduced, government should partner with local firms to establish industry as the cost of production are high and most local firms cannot meet.

\section{Conclusion}

Free port policy has been expatiated and stressed by well-known economists and policy makers as a form of global partnership for increase in income and wealth in the world. No country can survive on its own. Countries all over the world require collective effort from others to meet their basic needs. The study found that free port policy has both economic benefits as well as cost. Regardless of the side a country may find itself with implementing free port policy, the concept of free port policy should be ideal trade policy for all nations of the world. It was concluded that Ghana stands to gain from free port in the following ways; free port will bring about free market activities help to exploit comparative economic advantages. There will be no or low foreign exchange controls, no or low export-import duties, attract foreign direct investment, enjoy tax exemptions and generation of foreign exchange earnings. Other economic benefits of free port for Ghana were; promoting non-traditional exports, providing jobs and creating income, knowledge transfer and better infrastructure for the country. Notwithstanding these economic benefits, the country needs to take cognizance of certain challenges need to be addressed if she in opting for any free port policy.

\section{References}

[1] Jung, B.M. (2011) Economic Contribution of Ports to the Local Economies in Korea. The Asian Journal of Shipping and Logistics, 27, 1-30. https://doi.org/10.1016/S2092-5212(11)80001-5

[2] UNESCAP, T.D. \& KMI (2005) Free Trade Zone and Port Hinterland Development. United Nations Publications. ST/ESCAP/2.

[3] Sunak, R. (2016) The Free Ports Opportunity: How Brexit Could Boost Trade Manufacturing and the North.

[4] Khadi, O. (2015) The Maritime Industry of Ghana: Role of Our Ports, Challenges and Key Lessons from successful Maritime Nations, 0-64.

[5] USA TODAY, 2011.

http://onlinestore.usatoday.com/2011-usa-today-editions-c1101.aspx

[6] Ghana Ports \&amp; Harbours Authority: News. 
http://www.ghanaports.gov.gh/news

[7] Klepo, Ž. and Borozan, Đ. Free Zone-The Source of Socio-Economic. Faculty of Economics in Osijek, 75-91.

[8] Engman, M., Onodera, O. and Pinali, E. (2007) Export Processing Zones: Past and Future Role in Trade and Development. $O E C D, 1-70$.

[9] FIAS (2008) Special Economic Zones: Performance, Lessons Learned, and Implications for Zone Development. World Bank, 1-83. https://doi.org/10.1596/978-0-8213-8763-4

[10] Madani, D. (1999) A Review of the Role and Impact of Export Processing Zones.

[11] Aggarwal, A. (2007) Impact of Special Economic Zones on Employment, Poverty and Human Development, Work. Pap. https://ideas.repec.org/p/ess/wpaper/id1111.html

[12] Feaver, D. (2004) Aggressive Fringe Competition and International Trade. International Journal of Applied International Business, 1, 13.

[13] OECD (2010) Trade and the Economic Recovery: Why Open Markets Matter.

[14] Conforti, P. and Salvatici, L. Agricultural Trade Liberalization in the Doha round. Alternative Scenarios and Strategic Interactions between Developed and Developing Countries.

[15] Nam, C.W. and Radulescu, D.M. (2004) Do Corporate Tax Concessions Really Matter for the Success of Free Economic Zones? Economic Change and Restructuring, 37, 99-123. https://doi.org/10.1007/s10644-004-6831-6

[16] Chen, X. (1994) The Changing Roles of Free Economic Zones in Development: A Comparative Analysis of Capitalist and Socialist Cases in East Asia. Studies in Comparative International Development, 29, 3-25. https://doi.org/10.1007/BF02687146

[17] Kituyi, M. (2013) Maximizing Trade, Investment and Development Opportunities of Emerging Markets through Free Trade \& Special Economic Zones. http://unctad.org/en/pages/SGStatementDetails.aspx?OriginalVersionID=62

[18] KFEZ Success Story-Why KFEZ? - Korean Free Economic Zones. http://fez.go.kr/global/en/why/view-success.do?idx=61673

[19] Rotterdam, E.U. (2012) Erasmus Univerisity Rotterdam. Bachelor Thesis, The Freeport of Riga, Latvia.

[20] Bryman, A. (2008) Of Methods and Methodology. Qualitative Research in Organizations and Management. An International Journal, 3, 159-168.

[21] Yin, R.K. (2009) Case Study Research-Design and Methods. Clinics and Research, 2, 8-13.

[22] Simons, H. (2009) Case Study Research in Practice. SAGE, Thousand Oaks. https://doi.org/10.4135/9781446268322

[23] Welling, M., Rosen-zvi, M. and Hinton, G.E. (2005) Exponential Family Harmoniums with an Application to Information Retrieval. Advances in Neural Information Processing Systems, 17, 1481-1488.

[24] Field, A. (2005) Discovering Statistics using SPSS. SAGE, Thousand Oaks, 1-816. https://doi.org/10.1111/j.1365-2648.2007.04270_1.x

[25] Hanley, N., Shogren, J.F. and White, B. (2001) Introduction to Environmental Economics.

https://global.oup.com/ukhe/product/introduction-to-environmental-economics-97 $\underline{80199568734 ? \mathrm{cc}=\text { us\&lang=en \& }}$ 